\title{
The Effect of Service Quality on Satisfaction apropos Service Recipients of Divisional Secretariats in Colombo District in Sri Lanka
}

\author{
Nayanananda Nilwala ${ }^{1}$, Kennedy Gunawardana ${ }^{1} \&$ R. Lalitha S. Fernando ${ }^{2}$ \\ ${ }^{1}$ Faculty of Management Studies and Commerce, University of Sri Jayawardanapura, Sri Lanka \\ ${ }^{2}$ Head of the Department, Faculty of Public Administration, University of Sri Jayawaranapura, Sri Lanka \\ Correspondence: Nayanananda Nilwala, Faculty of Management Studies \& Commerce, University of Sri \\ Jayewardenepura, Sri Lanka. Tel: 94-72-796-9852. E-mail: nilwalanayanananda@gmail.com
}

\author{
Received: February 10, 2017 Accepted: February 25, 2017 Online Published: February 28, 2017 \\ doi:10.5539/jms.v7n1p127 URL: http://doi.org/10.5539/jms.v7n1p127
}

\begin{abstract}
A vast array of knowledge has been accumulated on the effect of service quality on customer satisfaction, particularly with a large number of studies over the past few years. However, the effect of service quality on satisfaction of service recipients in Divisional Secretariats in the Public Sector is relatively an unattended area by researchers. Hence, this study was carried out to evaluate the effect of service quality on satisfaction of service recipients of divisional secretariats. This particular organization was selected for the study as it is considered to be the most significant service provider in terms of statutory, social, economic and development in the country. A questionnaire survey and personal interviews were conducted to collect data by using the purposive sampling method. A modified questionnaire was prepared based on SERVQUAL instruments with two additional questions. A sample of 520 service recipients from 13 Divisional Secretariats in Colombo was drawn and it was represented by 40 from each division. Correlation analysis and multiple regression analysis were used to examine the relative impact of the service quality on satisfaction of service recipients. The study revealed that all the service quality attributes positively related to satisfaction of the service recipients. The findings of the study show that satisfaction of service recipients in terms of service quality has not met the expected level, which a divisional secretariat is deemed to provide for.
\end{abstract}

Keywords: service quality, service recipient, Divisional Secretariat, satisfaction

\section{Introduction}

In 1992, the Divisional Secretariat system was introduced to each division with the hope of delegating authority at the division level (Herath, 2008). The Author further reiterates that Divisional Secretariats are the institutes at the base level of the hierarchy, through which more than 90 percent of the government related services are delivered to the general public in Sri Lanka. At present, there are 332 Divisional Secretariat Divisions that include 14022 GramaNiladhari Divisions within the 25 Administrative Districts in the country as per Annual Report of Ministry of Home Affairs, 2015. Hence, the Divisional Secretariats being the institutes operating at the interface between the government and the general public are compelled to deliver services of high quality standards. The Division has today emerged as the new unit of administration in the delivery of services, implementation and operation of development programs. The nature and the scope of the division has quantitatively and qualitatively changed. The division level administration still functions as the closest administrative and decision-making unit to the people including those at grass-root level. This is also the unit through which essential services are delivered to the people and also to a great extent it is the implementing agency of the development programs and the coordinating agency of special programs. The Divisional Secretariat is now a much strengthened office with more staff to liaise/coordinate with agencies operating at the grass-root level along with the field officers such as technical supporting staffs. Kotler \& Lee (2007, cited by Kodithuwakku, 2007) state that one major role of the Government is to provide the necessary public services that neither the private sector nor the non-profit sector wants to handle or can deliver with the existing resources. In this context, Divisional Secretariat as a service provider needs to manage the service quality with existing resources and it has become so important to identify the customer expectations regarding service quality and delivery levels as well. The failure to do so would lead to frustration and dissatisfaction of the service recipients who would be either the general public or the various private and non-governmental organizations that would eventually be able to produce results in the events of occurrence of various levels of inefficiency and 
ineffectiveness. Further, a study carried out by the Asian Development Bank in the year 2006 has revealed that significant weaknesses exist in the Sri Lankan public administrative system in terms of its productivity and quality. This is applicable to the divisional secretariat as well. Some of the key problems that were discernible are attributed to bureaucratic controls, cumbersome processes and delays in providing services which tantamount to inherent weaknesses of the existing office system (Root et al., 2001; cited by Kodithuwakku, 2007). In this regard, Iqbal (2002) opined that the decisions taken by the bureaucracy - the high ranking officials of this sector have a direct bearing on the quality of service. Iqbal further, commented that the government service in Sri Lanka leaves much to be desired, since the tentacles of politics that have spread over the government service sector have incapacitated it from achieving the intended goals (World Bank, 2012). As per Tiecher et al. (2002) and cited by Ranaweera (2015), it is stated that in the previous years, government organizations had paid little attention to service quality or responsiveness to clients. As Iqbal (2002) pointed out that the government service of Sri Lanka is in a pathetic state of affairs because of the incessant political interference. Bwalya (2009) states that lack of dedication and the correct attitudinal orientation on the part of the service providers coupled with the less attractive remuneration package have triggered serious setbacks evoking a working environment of lethargy among the government servants amidst mixed feelings of despair and apathy among the service recipients. Withanage (2003) asserts that the government sector organizations have not been immune from the revolution that has swept through much of the commercial service sector over the past decade or so. According to Wisniewski \& Donnelly (1996) organizations operating under the government sector have also come to realize that not only they must look after the customer, but they must also take the opportunity to learn from them in terms of customer expectations and customer perceptions of service. In additions, Kotler \& Armstrong (2013), asserted that service provision should be interlaced with quality. Ranaweera (2015) states that the government administration facing critical situation in providing a quality government service. The Author reiterates that besides this, lack of proper training, dedication, attitudinal orientation, absence of adequate motivation, dearth of proper technology and inadequate remuneration, are contributory causes to the existing ills in the services. (Kamarck, 2007) notes that as a dynamic field, government administration has introduced reforms, new approaches and alternatives along with the winds of change in the economic and socio-political environments, apropos of how best to deliver government services. Organizations operating in this sector came to realize later in Lagos, that customer service and quality were critical strategic issues (Iqbal, 2002). Bakhtiari (2007) noted that the government services could be considered as being of high quality and excellence, if people received a high degree of satisfaction. Also people would consider that the government services provided are of high quality, when they find that the government has been responsive to their needs through the Divisional Secretariats. Public sector provision of goods and services, traditionally assumed a framework of monopoly in which the citizen has little choice, but in the present context the citizen expects quality service. Some of these goods and services were free at the point of delivery to the citizen and a few services and goods are being charged at concessionary prices, even though the tax payers contributed their share. Therefore, the citizen is a customer. Nevertheless, a key theme of new public management is given emphasis on the public as client and on customer choice. In view of that, some of the noteworthy reforms that were undertaken during the past decades for the promotion of country's open market economy which included removal of many administrative controls relevant to investment, financial reforms favoring investment, business, fiscal and other incentives to foreign investors that were needed to restructure the bureaucracy by way of introducing strategic orientation, market orientation and improved productivity. Hence, it is right time to measure the extent of the customer satisfaction related to the delivered service by evaluating customer expectations and perceptions. In the past, there were many transformations in Divisional Secretariats due to public complaints. Therefore, it is clear that the service provider should aim to match what is proffered to fulfill customer expectation in order to increase the level of customer satisfaction. In other words, the gap between the customer expectation and the perception of the service delivered should be minimized. Thus, it is imperative to take cognizance of the gap, to the effect that there could be a series of facts which are directly or indirectly linked to diverse reasons for the poor service delivery regarding customer satisfaction. Hence, this leads to the research question as to ascertain, how service qualities affect satisfaction of service recipients in Divisional secretariats.

\section{Literature Review}

Zeithaml et al. (2013) define services as deeds, processes and performances provided or coproduced by one entity or person for another entity or person. They broadly define service as the total effect of all economic activities, (output) which is not a physical product or construction that is generally consumed at the time-it is produced and provides added value in forms that are essentially intangible concerns of its first purchaser. They further stated the characteristics of services namely as: (a) Intangibility: services are performances or actions rather than objects. They cannot be seen, felt, tasted or touched in the same manner as there that can be felt as 
tangible goods, (b) Heterogeneity: services are performances, frequently produced by the human being and no two services will be precisely alike, (c) Perishability: refers to the fact that services cannot be saved, stored, resold, or returned.

Fogli (2006) defined service quality as a global judgment or attitude relating to a particular service; the customer's overall impression of the relative inferiority or superiority of the organization and its services. Parasuraman et al. (1988), Naeem \& Saif (2009) found that customer satisfaction is the outcome of service quality. Padgett \& Allen (1997) and others have conceptualized service experience as Psycho-motor Cognitive and Affective, reactions associated with a specific service event. As per Kotler (2000), satisfaction is the level of the person's felt state resulting from comparing a product's perceived performance in relation to the person's appreciation. It can be achieved by exactly understanding what a customer expects from an organization and also by evaluating the customer perception on the service delivery. Understanding customer satisfaction of different customer groups is important as the service provider is able to alter the service quality attributes in order to get inclined to provide for, in order to satiate the needs and wants of different customer groups. It is of utmost importance to managers because understanding service attributes that drive customer satisfaction help to identify that area for management intervention Lovelock \& Gummesson (2004). It is commonly seen that the service providers heavily adopt customer acquisition strategies and loyalty in their marketing plans. Fornell et al. (2006) claim that satisfied customers who have economic assets with high returns and low risk. Arnould \& Price (1993) noted that there exist a complex relationship between client expectation and satisfaction. They further state that the narrowness of the rating experience rather than relationship between expectation and outcome is shown to be central to its evaluation. Further, Boulding et al. (1993) affirmed the empirical findings from the two tests of the model indicated, among other things, that the two different types of expectations have opposing effects on perceptions of service quality and that the service quality perceptions positively affect intended behaviors. Service quality and Customer satisfaction have been conceptualized as a closely related construct. Beerli et al. (2004) stated that there is a positive relationship between these two constructs. Jamal \& Naser (2003) stated that service quality is the antecedent of customer satisfaction. Yee et al. (2010) found that service quality has a positive influence on customer satisfaction. Many researchers found that service quality is the antecedent of customer satisfaction (Kumar et al., 2010; Naeem \& Saif, 2009; Bedi, 2010).

In this study, the intention of the researcher is to examine how service quality dimensions relate to customer satisfactions in public sector organizations. Thus, the researcher found that a number of instruments have been developed to measure the quality of service provided by an organization and, through prior studies, such on the SERVQUAL model, developed by Parasuraman, Zeithaml, \& Berry (1985) and subsequently refined in 1988, 1991, 1993 and 1994 per (Parasuraman et al., 1988, 1991, 1993, and 1994), which is one of the widely used measures of service quality. The Parasuraman's Gap model of service quality was first introduced in 1985. In this model there are five gaps that are introduced by the pioneers of this model. The first gap is the customer gap and it is the difference between customer expectations and perceptions. Customer expectations are standards or reference points that customers bring into the service experience, whereas customer perceptions are subjective assessments of actual service experiences. Customer expectations often consist of what a customer believes should or will happen. Closing the gap between what customers expect and what they perceive is critical to deliver quality service. It forms the basis for the gap model. As per Zeithaml (2013), customer satisfaction and customer focus are so critical to the competitiveness of firms that any company interested in delivering quality services must begin with a clear understanding of its customers. Further, they suggested four other gaps other than the customer gap, the listening gap, the service design and the standard gap, the service performance gap and the communication gap. Parasuraman, Zeithaml, \& Berry (1988) identified five service quality dimensions through their pioneering research and that applies across a variety of service contexts. They are namely, 1) reliability: ability to perform the promised services dependently and accurately; 2) responsiveness: willingness to help customers and provide prompt services; 3 ) assurance: employees' knowledge and courtesy and their ability to inspire trust and confidence; 4) empathy: caring individualized attention given to customers and 5) tangibility: appearance of physical facilities, equipment, personnel and communication. This model is widely applied in many service sectors including public services (Keuh \& Voon, 2009). The ultimate goal is to close this gap by meeting or exceeding customer expectations. As per Siddiqi (2011) and based on his review of literature and research findings, it has revealed that relationship among service quality, customer satisfaction and customer loyalty and service quality attributes are positively related to customer satisfaction and customer satisfaction is positively related to customer loyalty in the retail banking setting in Bangladesh. In this regard, empathy demonstrates the highest positive correlation with customer satisfaction and tangibility shows the least positive correlation with customer satisfaction. As per Kumar (2009) and cited by Siddiqi stated that high quality service will result in high customer satisfaction and increase customer loyalty. Zaim et al. (2010) found that tangibility, 
reliability and empathy are important factors for customer satisfaction. Mengi (2009) found that responsiveness and assurance as important factors. Kumar et al. (2010) and Lai (2004) found that assurance, empathy, and tangibility are the important factors and Baumann et al. (2007) found that tangibles are not related to customer satisfaction and Ahmed et al. (2010) found out that empathy is negatively related with customer satisfaction. Baruah, Nath, \& Bora (2015) found that Reliability, Responsiveness and Empathy were different regarding male and female and regarding tangibility and assurance there was no difference. However, in Sri Lanka, there is no research area completed in level of Service quality and its effects on satisfaction of service recipients of divisional secretariats in the public sector.

\section{Research Question}

Hence, the research question focused here is to ascertain, how do service qualities affect satisfaction of service recipients of Divisional Secretariats?

\section{Objectives of the Research}

1) To evaluate service quality of the Divisional Secretariats.

2) To evaluate the satisfaction of service recipients in the Divisional Secretariats.

3) To examine the effect of service quality on satisfaction of service recipients.

4) To propose suggestions for policy decisions and recommendations apropos future. Policies regarding the service quality improvement in Divisional Secretariats

\section{Conceptual Framework Based on Literature}

In this study, based on available literature, researcher takes into consideration the satisfaction of the service recipients as the dependent variable. Zeithaml et al. (2013) state that customer satisfaction is influenced by specific service features, perceptions of service quality and price and in addition to that, such personal attributes as the customer's mood or emotional state as well as situational factors. Hence, to develop the conceptual framework the service quality is considered as the independent variable for this study as shown in Figure 1.

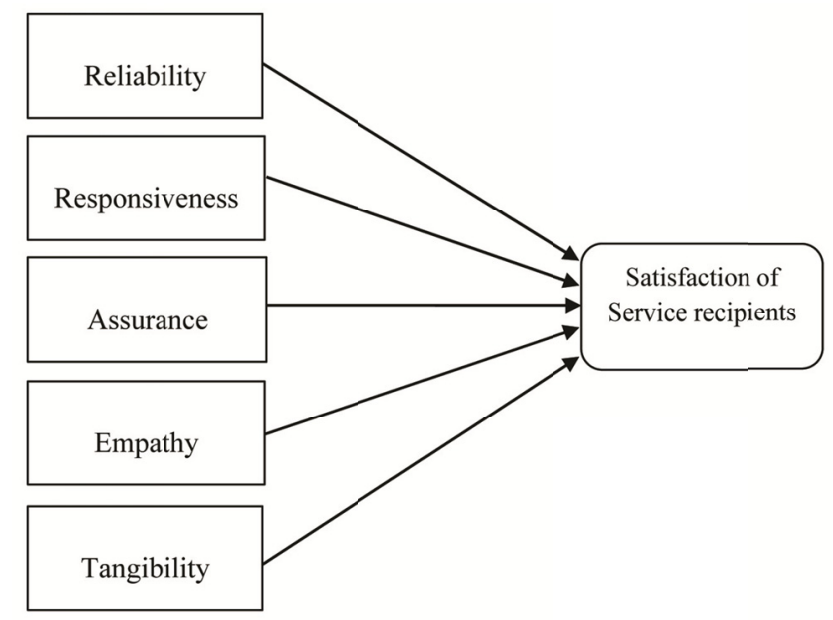

Figure 1. Schematic diagram of service quality and customer satisfaction

\subsection{Hypotheses}

As mentioned in the literature review service quality and customer satisfaction are closely related constructs. There is a positive relationship between the two constructs (Beerli et al., 2004; Rod et al., 2009; Al-hawari, 2008). Based on the aforementioned relationships, hypotheses can be developed as follows:

H1: Reliability significantly affects satisfaction of the service recipients in Divisional Secretariat.

H2: Responsiveness significantly affects satisfaction of service recipients in Divisional Secretariat.

H3: Empathy significantly affects satisfaction of the service recipients in Divisional Secretariat.

H4: Assurance significantly affects satisfaction of the service recipients in Divisional Secretariat.

H5: Tangibility significantly affects satisfaction of the service recipients in Divisional Secretariat. 


\section{Methodology}

\subsection{Study Area}

The study was conducted in Colombo district of Sri Lanka. This particular district was selected as the study area due to the fact that it has the highest and a diversified number of service recipients of the divisional administrative system. The Home Affairs Ministry which is the supervisory body of divisional Secretariats is also located in close proximity. In addition, it is situated in the main commercial centre and the administration city Colombo district. Hence, it was selected for the study.

\subsection{Population}

Sekaran \& Bougie (2014) defined population as the total of the entire group of people, events, or things that the researcher desires to investigate. Thus, the total number of service recipients of Divisional Secretariats is considered as the researched population in this study. According to the information available in Divisional Secretariats offices, there are about 300 to 500 of service recipients who visit the Divisional Secretariats on a public day. Hence, in this research the aforesaid population is considered as the number of service recipients of divisional secretariats.

\subsection{Sampling and Data Collection}

\subsubsection{Sample}

Sekaran \& Bougie (2014) state that the sampling is confined to specific types of people who can provide the desired information, either because they are the only ones who have possession of it, or conform to some criteria set by the researcher. Therefore, purposive sampling is employed. Krejcie \& Morgan (1970), Cohen (1969), Roscoe (1975), cited by Sekaran \& Boguie (2014) propose the rules factor to determine the sample size. Roscoe proposes that a sample size larger than 30 and less than 500 are appropriate for most researches. Thus, a sample of 520 service recipients was selected purposely and interviewed. Much of the data collection was conducted using a convenient method. It was decided to distribute the questionnaires among the service recipients. The sampling procedure was purposive because a simple random sampling was difficult to use, since there was no sampling frame. 40 recipients were selected from each Secretariat and it is considered that all Divisional Secretariats were thereby represented by more or less the same number of recipients from each Divisional Secretariat. Service recipients were selected for the interview in the mornings and the afternoons during public days of the weekdays due to reasons of convenience and time factor.

\subsubsection{Pre-survey}

Structured questionnaire was pre-tested and then finalized. It was administered to several service recipients of Divisional Secretariats in order to elicit the information about the quality of service as attributes perceived by customers who also are really in need. Seeking service qualities is more or less lined with the attributes of "SERVQUAL" model.

\subsubsection{Questionnaire}

The Questionnaire was designed to find out the demographic factors and other factors such as type of service, recipient, level of education ...et cetera, which would relate to the perceived service quality of the Divisional Secretariat and the level of satisfaction.

The Questionnaire was basically based on "SERVQUAL" (service quality) attributes. These attributes are included under the five dimensions of service quality proposed as Tangibility, Reliability, Responsiveness, Assurance and Empathy (Zeithaml \& Bitner, 2000). The responses were entered into a five point Likert scale, ranging from strongly disagree to strongly agree (Gerson, 2004). Twenty four questions were used to measure the perception of service quality along with the five dimensions and the additional question was included to assess the level of customer satisfaction.

\subsubsection{Data Collection}

The research is based upon the data collected from service recipients of Divisional secretariats in Colombo District. In this research data collection process it mainly concentrates on measuring perception of the service recipients in terms of service quality of divisional Secretariats to identify the perceived service quality. Service recipients of the Divisional Secretariats were selected due to two reasons that, 1) they were accessible to and represented as the customers of the organization and that, 2) they have a good understanding about the service quality provided by the Divisional Secretariat offices. Generally, during the data collection process, each service recipients' work place was visited and collection of data was mainly by administering a survey questionnaire and interview. 
The researcher distributed 540 questionnaires and all of them were collected. After verifying data and checking to ascertain which questionnaires were left uncompleted, 20 responses were deleted. Subsequently, the analysis was carried out on responses with 520, revealing a response rate of 96.3 percent of the Distributed questionnaires. The SPSS software version 22 was used to analyze the data.

\subsection{Analysis and Results}

The profile of the sample was analyzed with regard to its frequencies and distributions.

Table 1 shows the profile of respondents. Analysis of the data indicated that out of the 520 respondents, 53.7 percent of respondents were females and 46.3 percent of were males. Among them 11.5 percent were graduates, 52.7 percent were secondary education qualified, 35.2 were with primary schooling and six percent were post graduates. The data also revealed that 64 percent of service recipients were from the General Public, 23.5 percent were non-government organizations, 4.6 percent from the government sector and 7.9 percent were from the private sector; 1.5 percent of respondents belonged to 18-25 age category, 18.1 percent belonged to $26-35$ age range, 44.6 percent were from $36-40$ age category and 35.8 percent belonged to above 40 age group.

Table 1. Profile of respondents

\begin{tabular}{llll}
\hline Description & & Frequency & Valid Percent \\
\hline Gender & Male & 241 & 46.3 \\
& Female & 279 & 53.7 \\
& Total & 520 & 100 \\
\hline Age range & $18-25$ & 8 & 1.5 \\
& $26-35$ & 94 & 18.1 \\
& $36-40$ & 232 & 44.6 \\
& 40 above & 186 & 35.8 \\
& Total & 520 & 100 \\
\hline Education & Primary & 183 & 35.2 \\
& Secondary & 274 & 52.7 \\
& Graduate & 60 & 11.5 \\
& Post Graduate & 3 & 0.6 \\
& Total & 520 & 100 \\
\hline Service Recipient Category & Private Sector Organization & 41 & 7.9 \\
& Government Organization & 24 & 4.6 \\
& NGO Sector & 122 & 23.5 \\
& General Public & 333 & 64.0 \\
& Total & 520 & 100 \\
\hline
\end{tabular}

\section{Appropriateness for Analysis}

\subsection{Validity}

Validity is the measuring instrument which actually measures the property which is supposed to measure. There are methods suggested by scholars for testing the reliability and validity of a measurement instrument. It is also referred to as ensuring the goodness of measures. In the above measurement, the instrument used in researcher's first attempt for service quality was to establish content and face validity.

\subsection{Face Validity}

Face validity is also a measure of content but not as strong as establishing it through a literature review. In the present exercise it was done by showing the questions to a few known people who are experts in service quality in the research field.

\subsection{Content Validity}

Content validity ensures that the measure is inclusive of an adequate and representative set of items that covers the concept. This was established by the review of literature which included the research work of many authors on the subject of service quality in their attempts to conceptualize service quality. The next step was to test for the reliability.

\subsection{Reliability}

To test the reliability of the SERVQUAL instrument, the researcher computed the Cronbach's alpha coefficients. The overall reliability for the dependent variable is .950 representing reliability as shown in Table 2. Sekaran \& 
Bougie (2014) stated that 0.70 Cronbach Alpha for social research is acceptable. In this study computed alpha exceeds the average acceptable level. The checking for Cronbach Alpha reliability meets the acceptable cut off point of 0.70 (Nunnally, 1978; Saunders, Lewis, \& Thornhill, 2014; Field, 2014; Argyrous, 2014). The reliability statistics for reliability is .874 , Responsiveness is .958 , Assurance is .983 , Empathy is .964 and Tangible is .957 as shown in Table 3.

Table 2. Reliability statistics for dependent variables

\begin{tabular}{lll}
\hline Cronbach's Alpha & Cronbach's Alpha Based on Standardized Items & No of Items \\
\hline .950 & .954 & 3 \\
\hline
\end{tabular}

Table 3. Reliability statistics for independent variables

\begin{tabular}{llll}
\hline & Cronbach's Alpha & Based on Standardized Items & No of Items \\
\hline Reliability & .874 & .882 & 4 \\
Responsiveness & .958 & .959 & 4 \\
Assurance & .983 & .983 & 4 \\
Empathy & .964 & .964 & 5 \\
Tangibility & .957 & .958 & 4 \\
\hline
\end{tabular}

Table 4. Correlation among service quality dimension and satisfaction of service recipients

\begin{tabular}{lllllll}
\hline & Satisfaction & Reliability & Responsiveness & Assurance & Empathy & Tangibles \\
\hline Satisfaction & 1.000 & & & & & \\
Reliability & .346 & 1.000 & & & & \\
Responsiveness & .524 & .336 & 1.000 & 1.000 & & \\
Assurance & .395 & .401 & .443 & .338 & 1.000 & \\
Empathy & .400 & .348 & .362 & .370 & .323 & 1.000 \\
Tangibility & .416 & .302 & .390 & & & \\
\hline
\end{tabular}

Source: Survey data.

The Pearson Correlation analysis was applied to find out relationships between each of the variables of this study. The Pearson correlation analysis was obtained for three intervals scale variables. The sample size is (n) 520 and the significant level is 0.01 (p 0.01). As shown in the Table 4, the correlation (r) is .346 for reliability and the $p$ value is 0.000 , which is less than the significant level $(0.01)$. Therefore, it can be concluded that reliability and satisfaction of service recipients is positively related in the Divisional Secretariats. The correlation (r) of responsiveness is .524 and the significant level is 0.01 (p- value 0.01 ). The table shows that the p-value is 0.000 , which is less than 0.01 . Therefore, it can be concluded that there is a positive relationship between responsiveness and satisfaction of service recipients in the Divisional Secretariats. The correlation (r) of empathy is .400 and the p- value is 0.000 , which is less than 0.01 . Therefore, it can be concluded that empathy is positively related to satisfaction of service recipients in the Divisional Secretariats. The correlation (r) of assurance is .395 and the $p$ - value is 0.000 , which is less than the significant level $(0.01)$. Therefore, it is concluded that assurance is positively related to satisfaction of service recipients in the Divisional Secretariats. The correlation ( $r$ ) of tangibles is .416 and the p- value is 0.000 , which is less than the significant level $(0.01)$. Therefore, it is concluded that tangibles is positively related to satisfaction of service recipients in the Divisional Secretariats.

\section{Hypotheses Test}

Table 5. Regression results of the satisfaction of service recipients of divisional secretariats

\begin{tabular}{llll}
\hline Predictor & Standardized Regression Coefficient & T-Value & Sig. \\
\hline (Constant) & - & 9.418 & .000 \\
Reliability & .120 & 2.841 & .005 \\
Responsiveness & .040 & .923 & .356 \\
Assurance & .172 & 3.884 & .000 \\
Empathy & .211 & 5.046 & .000 \\
Tangibility & .232 & 5.532 & .000 \\
R & $.551^{\mathrm{a}}$ & & \\
R squares & .303 & & \\
Adjusted $\mathrm{R}^{2}$ & .296 & & \\
F & 44.718 & & \\
\hline
\end{tabular}

Source: Survey data. 
The hypotheses were tested by using Simple Multiple Regression Analysis. Table 5 shows that correlation (r) is .554 and it is revealed that there is 55 percent relationship between service quality and satisfaction of service recipients in divisional secretariat (Saunders, Lewis, \& Thornhill, 2014; Field, 2014; Sekaran \& Bougie, 2014; Argyrous, 2014). In contrast to correlation coefficient, the coefficient of determination (regression confident) can be used to assess the strength of relationship between dependent variable and one or more independent variables. The coefficient of determination ( $\mathrm{r}$ square) can take on any value between 0 and +1 . As shown in Table 5, ( $\mathrm{r}$ square) calculated coefficient of determination is 0.296 . Therefore 29 percent of service recipients reveal satisfaction which explains quality of service in Divisional secretariat. The F -test result is 44.718 with a significance of .000. It can be concluded that there is a significant effect of service quality on satisfaction of service recipients of Divisional secretariat. Table 5, shows the Standardized Regression Coefficient for .120 as reliability, .172 as assurance, .211 as empathy and .232 as tangibles respectively, except responsiveness. The regression coefficient of responsiveness is s.040 with a significance of .356. Therefore, H1, H3, H4 and H5 can be postulated at the $\mathrm{p}<0.05$ level. $\mathrm{H} 2$ cannot be postulated at the $\mathrm{p}<0.05$ level.

\section{Conclusions}

Based on hypotheses test, it reveals that reliability, assurance, empathy and tangibles have significant effect on satisfaction of service recipients of Divisional Secretariats except for responsiveness dimension. Further, it reveals that certain dimensions of service quality are positively correlated to satisfaction of service recipients. This positive relationship signifies that unlike in the case of responsiveness, satisfaction of service recipients increases with regard to reliability, assurance, empathy and tangibles. That means service quality dimensions positively relate to satisfaction of service recipients in the Divisional Secretariats. The performance of Assurance and Reliability service quality dimension are good in relation to their importance placed by the service recipients. However, responsiveness is much lower in the service quality compared to the other major dimensions. Service qualities of divisional secretariat are at a moderate level. It implies that there exists a potential situation to improve the service quality. Satisfaction of service recipients is at an average level and it is necessary to pay more attention on relevant areas that affect enhancement level of satisfaction.

In contrast, overall satisfaction is an affective/emotional response to a perceived discrepancy between expectations and perceptions. As a process in time, service quality occupies a foremast position and leads to overall customer satisfaction (Caruana \& Malta, 2000). Service quality is only one of the service factors contributing to customer satisfaction judgement (cited by Carana \& Malta, 2000; Cronin \& Taylor, 1992; Rayter et al., 1997; Spreng \& Makoy, 1996). Accordingly, there are clearly other antecedents. Thus, satisfaction of the service recipients of divisional secretariats also can be an outcome other than service quality regarding personal attributes such as customer mood or emotional state and situational factors. A significant relationship exists between the overall satisfaction of service level quality and gender in respect of overall satisfaction. It is noteworthy that the other service recipient category has a fairly low expectation level than those of the government and non-government / private sector service recipients. Service recipients are not satisfied with the existing office operating systems and days. With regard to policy formulation more attention is needed to improve the reliability, responsiveness and assurance dimensions of service quality. There is a significant increase of satisfaction of service recipients through tangibles and empathy.

To improve the service recipient's level of satisfaction, Divisional secretariat with its services, needs to serve service recipients better. Divisional secretariat can develop a strong service recipient—orientation, further improvements by eliminating existing weaknesses of service delivery systems, training for employees to be more responsive to service recipients, improving facilities with modern technology to ease service delivery with minimizing human interaction in public services. It requires a service recipient orientation culture within the organization.

\section{References}

Ahmed, I., Nawaz, M., Usman, A., Shaukat, M., Ahmad, N., \& Iqbal, H. (2010). Impact of Service Quality on Customers' Satisfaction: Empirical evidence from telecom sector of Pakistan. Interdisciplinary Journal of Contemporary Research in Business, 1(12), 98-113.

Al-Aali A., Khurshid, M. A., Nasir, N. M., \& Al-Aali, H. (2011). King Saudi University. Retrieved from $\mathrm{https} / / \mathrm{www} \cdot$ researchgate.net/publication/256227535

Albert, C. (2002). Service Loyalty: The Effect of Service Quality and the Mediating Role of Customer $\begin{array}{llll}\text { Satisfaction. European Journal of } & \text { Marketing, 36(7/8), }\end{array}$ https://doi.org/10.1108/03090560210430818

Al-hawari, M. (2008). The Influence of Traditional Service Quality Factors on Customer Satisfaction: A Practical 
Study within the Context of Australian Banking. The Business Review, Cambridge, 11(2), 114-119.

Argyrous, G. (2012). Statistics for Research (3rd ed.). New Delhi, India: SAGE Publications India Private Ltd.

Bakhtiari, P. (2007). Strategy-Focused Organization. Translated, 4, 3-11.

Banmann, C., Burton, S., Elliott, G., \& Kehr, H. M. (2007). International Journal of Bank Marketing, 25(2).

Baumann, C., Burton, S., Elliott, G., \& Kehr, H. (2007). Prediction of attitude and behavioural intentions in retail banking. The International Journal of Bank Marketing, 25(2), 102-116. https://doi.org/10.1108/02652320710728438

Bedi, M. (2010). An integrated framework for service quality, customer satisfaction and behavioural responses in Indian Banking industry: a comparison of public and private sector banks. Journal of Services Research, 10(1), 157-172.

Beerli, A., Martin, J. D., \& Quintana, A. (2004). A model of customer loyalty in the retail banking market. European Journal of Marketing, 38(1/2), 253-275. https://doi.org/10.1108/03090560410511221

Bhatnager, S. (2014). Public Service Delivery: Role of Information and Communication Technology in Improving Governance and Development Impact. Retrieved from $\mathrm{http} / /$ digitalcommons.ilr.cornell.edu/intl/364

Bryman, A., \& Bell, E. (2013). Business Research Methods (South Asia edition). New Delhi, India: Saurabh Printers, Pvt. Ltd.

Bwalya, K. J. (2009). Factors affecting the adoption of e-government in Zambia. The Electronic Journal on Information Systems in Developing Countries, 4, 1-13.

Caruana, A., \& Malta, M. (2002). Service Loyalty-The effects of Service Quality and the Mediating Role of Customer Satisfaction. European Journal of Marketing, 36(7/8), 811-828. https://doi.org/10.1108/03090560210430818

Cheng, H., Kotler, P., \& Lee, N. R. (1971). Social Marketing for Public Health, An Introduction.

Debasish, B., Thueswar, N., \& Dimpi, B. (2015). Impact of service quality Dimensions on Customer Satisfaction in Telecom Sector. International Journal of Engineering Trends and Technology, 27(2). Retrieved from http//www.ijettjournal.org

Fen, Y. S., \& Lian, K. M. (2001). Service Quality and Customer Satisfaction: Antecedents of Customer's Re-Patronage Intentions. Sunway Academic Journal, 4.

Field, A. (2013). Discovering statistics using IBM SPSS statistics. And sex, drugs and rock'n' roll (4th ed.). London, England: Sage.

Fogli, L. (2006). Customer Service Delivery. San Francisco: Jossey-Bass.

Fornell, C., Mithas, S., Forrest, V., Morgeson III., \& Krishnan, M. S. (2006). Customer Satisfaction and Stock Prices: High Returns, Low Risk. Journal of Marketing, 70, 3-14. American Marketing Association. https://doi.org/10.1509/jmkg.2006.70.1.3

Gaur, S. A., \& Gaur, S. S. (2014). Statistical Methods for Practice and Research, A Guide to Data Analysis Using SPSS (2nd edition). New Delhi, India: SAGE Response.

Gilmore, A. (2003). Services Marketing and Management. Thousand Oaks, California: Sage Publications Ltd.

Gronroos, C. (1984). A service quality model and its marketing implications. European Journal of Marketing, 18(4). In C. Amistead (Ed.). (1994), The Future of Service Management. Buddles Ltd. UK. https://doi.org/10.1108/EUM0000000004784

Herath, H. M. A. (2008). Grassroot Institutions for Regional Development: Sri Lankan Experience. Vidyodaya J. of Humanities and Social Science, 2, 305-334.

Heskett, J. L. (1986). Managing in the service economy. Brighton: Haevard Business School Press. In C. Amistead (Ed.). (1994), The Future of Service Management. Buddles Ltd. UK.

Hussaina, M. K. F., \& Bandara, R. A. (n.d.). Study on Public Sector Good Governance: with Special Reference to the University of Colombo.

Iqbal, M. C. M. (2002). The Public Service of Sri Lanka. Published Annual Report in the state of Human Rights in Sri Lanka.

Johnston, R. (1997). Identifying the Critical determinants of Service Quality in Retail Banking: Importance and 
effect. International Journal of Bank Marketing, 111-116. https://doi.org/10.1108/02652329710189366

Kamarck, E. C. (2007). The End of Government ...As We Know It: Making Public Policy Work. Boulder, CO.

Kazi, O. S. (2011). Interrelation between Service Quality Attributes, Customer Satisfaction and Customer Loyalty in the Retail banking Sector in Bangladesh. International Journal of Business and Management, 3(3). Retrieved from www.ccsenet.org/ijbm

Kodithuwakku, S. S. (1993). A Market Assessment of the Ornamental Fish Trade between Sri Lanka and the United Kingdom.

Kodithuwakku, S. S. (2007). The Quality of Service Provided by the Divisional Secretariats in the Central Province of Sri Lanka. Agri-Business Centre, Faculty of Agriculture, University of Peradeniya, SriLanka

Kotler, P. (2000). Marketing Management. Upper Saddle River, New Jersey: Prentice Hall Inc.

Kotler, P., \& Armstrong, G. (2013). Principles of Marketing (14th ed.). Edinburgh Gate Harlow Essex, England: Pearson Education.

Kumar, M., Fong, T. K., \& Vincent, C. (2010). Comparative Evaluation of Critical Factors in Delivering Service Quality of Banks, an application of dominance analysis in SERVEQUAL model. International Journal of Quality \& Reliability Management, 27(3), 351-377. https://doi.org/10.1108/02656711011023320

Kumar, M., Kee, F. T., \& Manshor, A. T. (2009). Determining the Relative Importance of Critical factors in delivering service quality of banks: an application of dominance analysis in SERVEQUAL model. Managing Service Quality, 19(2). https://doi.org/10.1108/09604520910943198

Kumar, S. A., Mani, B. T., Mahalingam, S., \& Vanjikovan, M. (2010). Influence of Service Quality on Attitudinal Loyalty in Private Retailing Bank: an empirical study. IUP Journal of Management Research, 9(4).

Liu, C., \& Arnett, K. P. (2000). Exploring the Factors associated with Web Site success in the Context of

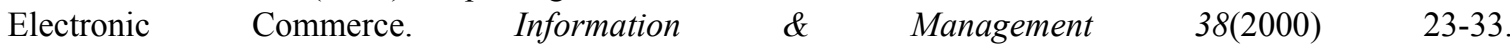
https://doi.org/10.1016/S0378-7206(00)00049-5

Lovelock, C., \& Gummesson, E. (2004). Whither services marketing? In search of a new paradigm and fresh perspectives. Journal of Service Research, 7(1), 20-41. https://doi.org/10.1177/1094670504266131

Mengi, P. (2009). Customer satisfaction with Service Quality: an empirical study of Public and Private sector Banks. IUP Journal of Management Research, 8(9).

Ministry of Home Affaires Annual Progress Report. (2015). Ministry of Home Affairs, Sri Lanka.

Naeem, H., \& Saif, I. (2009). Service Quality and its impact on Customer satisfaction: an empirical evidence from the Pakistani Banking sector. The International Business and Economics Research Journal, 8(12), 99.

Nunnally, J. C. (1978). Psychometric theory. New York: McGraw Hill.

Padgett, D., \& Allen, D. (1997). Communicating experiences: A narrative approach to creating service brand image. Journal of Advertising, 26(4), 49-62. https://doi.org/10.1080/00913367.1997.10673535

Parasuraman, A., Berry, L. L., \& Zeithaml, V. A. (1985). A Conceptual Model of Service Quality and Its Implications for Future Research. Journal of marketing, 49(4), 41. https://doi.org/10.2307/1251430

Parasuraman, A., Berry, L. L., \& Zeithaml, V. A. (1988). SERVQUAL: A multiple-item scale for measuring consumer perceptions of service quality. Journal of Retailing, 64(1), 12.

Parasuraman, A., Berry, L. L., \& Zeithaml, V. A. (1993). More on Improving Service Quality Measurement. Journal of Retailing, 69(1), 140. https://doi.org/10.1016/S0022-4359(05)80007-7

Prabha, R. M., Soolakshna, D. L. B., \& Perunjodi, N. (2010). Service quality in the public service. International Journal of Management and Marketing Research, 3(1). Retrieved from http//ssrn.com/abstract=1668833

Price, L. L., \& Arnould, E. J., \& Deibler, S. L. (1995). Consumers' Emotional Responses to Service Encounters, The Influence of the Service Provider. International Journal of Service Industry Management, 6(3), 34-63. https://doi.org/10.1108/09564239510091330

Ranaweera, H. M. B. P. (2015). ICT Applications and Service Quality of Government service. International Journal of Economics, Commerce and Management, 3(1). Retrieved from http//ijecm.co.uk/

Rod, M., Ashill, N., Shao, J., \& Carruthers, J. (2009). An examination of the relationship between service quality dimensions, overall internet banking service quality and customer satisfaction: A New Zealand study. 
Marketing Intelligence \& Planning, 27(1), 103-126. https://doi.org/10.1108/02634500910928344

Rust, R. T., \& Zahorik, A. J. (1993). Customer Satisfaction, Customer Retention and Market Share. International Journal of Retailing, 69(2). https://doi.org/10.1016/0022-4359(93)90003-2

Saunders, M. N. K., Lewis, P., \& Thornhill, A. (2012). Research Methods for Business Students (6th ed.). Harlow, England: Pearson Education.

Siddiqui, M., \&Shoaib, A. (2011). Measuring performance through capital structure: Evidence from banking sector of Pakistan. African Journal of Business Management, 5(5), 1871-1879.

Uma, S., \& Bougie, R. (2014). Research Method for Business, A Skill Building Approach (15th ed.). New Delhi, India: Wiley India (P) Ltd.

Ushantha, C. R. A., Wijerathna, A. W., \& Achchuthan, S. (2014). An Assessment of Retail service quality: An empirical study of the Sri Lankan Super Markets. Developing Country Studies, 4(3). Retrieved from www.iiste.org

Voon, B. H., Kueh, K., Unggah, L., \& Chali, R. (2009). Customers' perception of restaurant service quality: Evidence from Malaysia. Social and Management Research Journal, 6(1), 3350.

Wakefield, L. K., \& Blodgett, G. J. (1996). The Effect of Servicescape on Customers' Behavioral Intentions in Leisure Service Settings. The Journal of Services Marketing, 10(6), 45-61. https://doi.org/10.1108/08876049610148594

Wisniewski, M., \& Donnelly, M. (1996). Measuring service quality in the public sector: the potential for SERVQUAL. Total Quality Management, 7(4), 357-365. https://doi.org/10.1080/09544129650034710

Withanage, D. (2003). "e-Sri Lanka" The Use of ICTs for Poverty Reduction. Retrieved from http://zunia.org/post/the-use-of-icts-forpoverty-reduction/

World Bank Report. (2012).

Zaim, H. et al. (2010). Service quality and determinants of customer satisfaction in Hospitals. Turkish Experience, International Business \& Economics Research Journal, 9(5).

Zaim, H., Bayyurt, N., \& Zaim, S. (2010). Service quality and determinants of customer satisfaction in hospitals: Turkish experience. International Business \& Economics Research Journal, 9(5), 51-58.

Zeithaml, V. A., \& Bitner, M. J. (1996). Services Marketing. New York, N.Y.: McGraw-Hill.

Zeithaml, V. A., \& Bitner, M. J. (2000). Services Marketing: Integrating customer focus across the firm (2nd ed.). Boston, M.A: Irwin/ McGraw-Hill.

Zeithaml, V. A., Berry, L. L., \&Parasuraman, A. (1996). The behavioral consequences of service quality. Journal of Marketing, 60(2), 31-46. https://doi.org/10.2307/1251929

Zeithaml, V. A., Binter, M. J., Gremler, D. D., \& Pandit, A. (2013). Service Marketing, Integrating Customer Focus Across the Firm. New Delhi: McGraw Hill Education (India) Private Limited.

Zeithaml, V. A., Parasuraman, A., \& Berry, L. L. (1990). Delivering Quality Service. New York, N.Y.: The Free Press.

\section{Appendix A}

Questionnaire for Survey on Service Quality on Satisfaction of Service Recipients in Divisional Secretariats in Colombo District in Sri Lanka

\begin{tabular}{|c|c|c|c|c|c|}
\hline \multicolumn{6}{|l|}{$\begin{array}{l}\text { Service quality perception of Divisional secretariats } \\
\text { Perceptions Statements in the Reliability Dimension }\end{array}$} \\
\hline & \multicolumn{3}{|c|}{$\begin{array}{l}\text { Strongly } \\
\text { Disagree }\end{array}$} & \multicolumn{2}{|c|}{$\begin{array}{l}\text { Strongly } \\
\text { Agree }\end{array}$} \\
\hline 1. When Divisional Secretariat promises to do something by a certain time, it is done & 1 & 2 & 3 & 4 & 5 \\
\hline 2. Divisional Secretariat performs the service right at the first time itself. & 1 & 2 & 3 & 4 & 5 \\
\hline 3. Divisional Secretariat provides its services it promised, with no delay. & 1 & 2 & 3 & 4 & 5 \\
\hline 4. Divisional Secretariats insists on error-free records. & 1 & 2 & 3 & 4 & 5 \\
\hline
\end{tabular}




\begin{tabular}{|c|c|c|c|c|c|}
\hline Statements in the Responsiveness Dimension & & & & & \\
\hline $\begin{array}{l}\text { 1. Divisional Secretariat keeps customers informed ahead, about when services will be } \\
\text { performed. }\end{array}$ & 1 & 2 & 3 & 4 & 5 \\
\hline 2. Employees in Divisional Secretariat give you prompt service. & 1 & 2 & 3 & 4 & 5 \\
\hline 3. Employees in Divisional Secretariat are always willing to help you. & 1 & 2 & 3 & 4 & 5 \\
\hline 4. Employees in Divisional Secretariat are never too busy to respond to your request. & 1 & 2 & 3 & 4 & 5 \\
\hline
\end{tabular}

\section{Statements in the Assurance Dimension}

1. The helpful positive attitude of the employees in Divisional Secretariat instills confidence in you.

2. You feel safe in your transactions with the Divisional Secretariat.

3. Employees in Divisional Secretariat are consistently courteous to you.

4. Employees in Divisional Secretariat are knowledgeable to answer your questions.

\begin{tabular}{|c|c|c|c|c|c|}
\hline \multicolumn{6}{|l|}{ Statements in the Empathy Dimension } \\
\hline 1. Divisional Secretariat gives you individual attention. & 1 & 2 & 3 & 4 & 5 \\
\hline 2. Divisional Secretariat has employees who give you personal attention. & 1 & 2 & 3 & 4 & 5 \\
\hline 3. Divisional Secretariat has your best interests at heart. & 1 & 2 & 3 & 4 & 5 \\
\hline 4. Employees of Divisional Secretariat understand your specific needs. & 1 & 2 & 3 & 4 & 5 \\
\hline 5. Divisional Secretariat has operating hours that are convenient to all its customers. & 1 & 2 & 3 & 4 & 5 \\
\hline
\end{tabular}

\section{Statements in the Tangibles Dimension}

1. Divisional Secretariat has modern impressive smart equipment.

2. Divisional Secretariat's physical facility layout is visually appealing.

3. Divisional Secretariat's employees appear neat and they look presentable.

\begin{tabular}{lllll}
1 & 2 & 3 & 4 & 5 \\
1 & 2 & 3 & 4 & 5 \\
1 & 2 & 3 & 4 & 5 \\
\hline
\end{tabular}

\section{Overall satisfaction of service quality of Divisional Secretariat.}

I am personally satisfied with the service quality which is delivered by the divisional secretariat. $\quad \begin{array}{lllll}5 & 2\end{array}$

Thus, it can be said that a Divisional Secretariats in Colombo District is a quality service provider. $\quad \begin{array}{lllll}4 & 2 & 3\end{array}$

Therefore I can say that the quality of service rendered by the district secretariat to people is at $1 \quad 2 \quad \begin{array}{lllll}4 & 2\end{array}$

satisfactory level.

\section{Copyrights}

Copyright for this article is retained by the author(s), with first publication rights granted to the journal.

This is an open-access article distributed under the terms and conditions of the Creative Commons Attribution

license (http://creativecommons.org/licenses/by/4.0/). 